\title{
ANALISIS DAN PERANCANGAN SISTEM PAKAR PENENTUAN PENYAKIT KUCING MENGGUNAKAN METODE FORWARD CHAINING BERBASIS WEB
}

\author{
${ }^{1}$ Sintia Dardanela Cecilia, ${ }^{2}$ Mungki Astiningrum, ${ }^{3}$ Yuri Ariyanto \\ Program Studi Teknik Informatika, Jurusan Teknik Elektro, Politeknik Negeri Malang \\ chintyadardanela@gmail.com', mama.zahra@gmail.com², yuri.bjn@,gmail.com ${ }^{3}$
}

\begin{abstract}
Abstrak
Kucing menjadi hewan favorit untuk pecinta hewan yang ingin memelihara hewan. Apabila kucing sakit biasanya dilakukan oleh pakar/ahli penyakit hewan, namun sebenarnya pemelihara kucing juga bisa melakukan diagnose apabila kucing mengalami suatu gejala penyakit. Sistem pakar merupakan sebuah sistem yang digunakan untuk memecahkan masalah yang bisa diselesaikan oleh orang awam atau selain pakar. Sistem pakar penentuan penyakit kucing menggunakan metode forward chaining yang dimulai dengan mencari fakta terlebih dahulu dan metode certainty factor $(\mathrm{CF})$ untuk proses perhitungan tingkat kepercayaan di setiap rulenya. Sistem memberikan nilai keputusan berdasarkan gejala yang dialami, dan nilai keyakinan CF terhadap gejala. Pengujian fungsionalitas terhadap 14 penyakit dalam aliran data dengan metode black-box testing menunjukkan bahwa sistem pakar untuk mendiagnosa penyakit kucing telah memenuhi kebutuhan yang dijabarkan pada tahap analisis kebutuhan. Berdasarkan penilaian pakar terhadap ketepatan output sistem diperoleh akurasi sebesar $86,33 \%$. Keseluruhan hasil pengujian ini menunjukkan bahwa sistem pakar penentuan penyakit kucing dapat membantu pakar maupun orang awam untuk mendeteksi penyakit yang diderita kucing.
\end{abstract}

Kata kunci : certainty factor, forward chaining, sistem pakar, kucing

\section{Pendahuluan}

1.1 Latar Belakang

Saat ini kucing merupakan salah satu hewan peliharaan terpopuler di dunia. Ada banyak jenisjenis kucing yang bisa dijadikan peliharaan sesuai dengan selera. jika ingin memelihara kucing ada baiknya kita juga mengetahui jenis-jenis penyakit pada kucing agar kita bisa melakukan pencegahan dan segera memberikan pertolongan. untuk kucing yang mempunyai bulu yang tebal dan banyak diperlukan ekstra perhatian agar kucing tetap sehat dan bahagia. Selain itu kucing merupakan hewan peliharaan predator yang hebat di dunia. Satu-satu nya bahaya yang ditimbulkan oleh kucing adalah penyakit rabies akibat gigitan kucing dan juga cakaran dari kuku kucing yang sangat perih dan menyakitkan. Untuk penyakit pada kucing bisa digolongkan hampir sama dengan penyakit manusia. Penyakit kucing ada yang ringan dan ada yang berat.

Secara umum, sistem pakar merupakan sistem yang berusaha mengimplementasikan pengetahuan manusia ke komputer yang dirancang untuk memodelkan kemampuan menyelesaikan masalah seperti layaknya seorang pakar.

Sistem pakar ini juga akan dapat membantu aktivitas para pakar sebagai asisten yang berpengalaman dan mempunyai pengetahuan yang dibutuhkan.

Sudah banyak sistem pakar yang dikembangkan di berbagai bidang seperti bidang kedokteran, bidang ekonomi, elektronika, komputer, pertanian dan bidang lainnya. Sistem pakar yang dikembangkan dalam bidang pertanian misalnya adalah "Perancangan Sistem Pakar Diagnosis Penyakit Utama Tanaman Kelapa Sawit (Dewi Yanti, 2008)". Sistem pakar ini menggunakan metode inferensi Forward Chaining, yaitu proses inferensi yang memulai pencarian dan premis atau data menuju konklusi. Sistem ini cukup bermanfaat dalam hal memberikan informasi sehingga membantu user atau pengguna dalam menangani penyakit tanaman kelapa sawit.

Saat ini, kemajuan yang pesat dari teknologi computer sangat membantu manusia dalam segala bidang tidak terkecuali juga dalam bidang hewan. Sistem pakar menyediakan informasi penunjang serta membantu mengidentifikasi penyakit pada kucing yang mampu memberikan solusi mengenai cara mencegah dan cara mengatasinya. Sistem pakar dibangun menggunakan bahasa pemrograman web PHP dengan koneksi database pada MySQL. Keduanya dipilih karena kemampuan lintas platform dan sifatnya yang open source. Certainty Factor dipilih karena termasuk salah satu metode yang dapat menyelesaikan masalah ketidakpastian dalam sistem pakar[KUS-08].

Pada penelitian sebelumnya, berdasarkan penilaian pakar tehadap output sistem yang menggunakan metode certainty factor untuk kasus identifikasi penyakit dengan gejala demam diperoleh hasil yang cukup baik, yaitu sebesar $74 \%[\mathrm{DAN}-10]$. 
Oleh karena itu penulis mendapatkan ide untuk memanfaatkan teknologi komputer yaitu merancang aplikasi sistem pakar yang digunakan untuk membantu dalam mendiagnosis penyakit yang menyerang pada hewan kucing. Program aplikasi sistem pakar ini mendapat masukkan atau informasi dari para dokter hewan dan beberapa sumber lain seperti buku, internet browser untuk dijadikan sebagai acuan bagi seorang pakar melakukan diagnosa terhadap penyakit hewan kucing yang diberikan oleh program aplikasi sistem pakar ini diharapkan mampu membantu para pecinta kucing maupun kalangan umum yang memerlukan informasi ini.

\section{Metode}

Metode pengembangan untuk membangun sistem pakar meliputi : a.) analisis situasi dan identifikasi kebutuhan data dan keluaran yang mungkin, b.) menentukan realsai antara data dan aturan sebagai dasar dalam pembuatan kuputusan. Metode penelusuran yang digunakan adalah forward chaining dan keyakinan menggunakan certainty factor.

\subsection{Rule-based Sistem Pakar}

Secara umum representasi penegahuan yang digunakan dalam sistem pakar menggunakan aturan IF-THEN. Pengunaan pernyataan IFTHEN untuk menyatakan aturan-aturan biasa juga disebut dengan rule-based system (basis aturan sistem pakar). Pada penelitian ini penelusuran pada basis aturan menggunakan inferensi forward chaining, yang mana sistem menganalisis persoalan dengan mencari fakta yang sesuai dalam bagian $I F$ dengan hasil pada bagian THEN.

Ada dua pendapat mengenai implementasi metode inferensi forward chaining. Pertama, dengan membawa seluruh data yang didapat ke sistem pakar. Kedua, membawa bagian-bagian penting saja dari data ke sistem pakar. Cara kedua lebih cenderung dapat menghemat waktu dan biaya, karena hanya data penting saja yang diambil.

\subsection{Faktor Keyakinan (Certainty Factor)}

Certainty factor merupakan salah satu teknik yang digunakan untuk menyatakan keyakinan fakta atau hipotesis. Oleh karena itu, CF digunakan untul menunjukan seberapa akurat nilai keyakinan dan ketidakyakinan yang independen satu sama lain. CF dapat diekspresikan ke dalam sautau persamaan berikut

$\mathrm{CF}(\mathrm{H}, \mathrm{E})=\mathrm{MB}(\mathrm{H}, \mathrm{E})-\mathrm{MD}(\mathrm{H}, \mathrm{E})$

$\mathrm{CF}$ hipotesis $\mathrm{H}$ atas munculnya evidence $\mathrm{E}$ dinotasikan dengan $\mathrm{CF}(\mathrm{H}, \mathrm{E})$ yang memiliki persamaan $\mathrm{MB}(\mathrm{H}, \mathrm{E})$ atau ujuran keyakinan terhadap hipotesis $\mathrm{H}$ atas munculnya evidence $\mathrm{E}$ dikurangi dengan $\mathrm{MD}(\mathrm{H}, \mathrm{E})$ sebagai ukuran ketidakyakinan terhadap hipotesis $H$ atas munculnya evidence E. selanjutnya diketahui rumus dasar $\mathrm{CF}$ untuk kaidah IF $\mathrm{E}$ THEN $\mathrm{H}$ sebagai berikut : :

$\mathrm{CF}(\mathrm{E}, \mathrm{e})=\mathrm{CF}(\mathrm{E}, \mathrm{e}) * \mathrm{CF}(\mathrm{H}, \mathrm{E})$

Dimana $\mathrm{CF}(\mathrm{H}, \mathrm{e})$ merupakan notasi $\mathrm{CF}$ yang didasarkan pada ketidakyakinan evidence e. $\mathrm{CF}(\mathrm{E}, \mathrm{e})$ merupakan $\mathrm{CF}$ dari kejadian $\mathrm{E}$ yang dipengaruhi evidence e, dapat dinotasikan dengan persamaan berikut

$\mathrm{CF}(\mathrm{E}, \mathrm{e})=\min \left[\mathrm{CF}\left(\mathrm{e}_{1}\right), \mathrm{CF}\left(\mathrm{e}_{2}\right), \ldots, \mathrm{CF}\left(\mathrm{e}_{\mathrm{n}}\right)\right]$

Apabila gabungan estimasi menggunakan operator AND, atau

$\mathrm{CF}(\mathrm{E}, \mathrm{e})=\max \left[\mathrm{CF}\left(\mathrm{e}_{1}\right), \mathrm{CF}\left(\mathrm{e}_{2}\right), \ldots, \mathrm{CF}\left(\mathrm{e}_{\mathrm{n}}\right)\right]$

Apabila gabungan estimasi operator $\mathrm{OR} C F(H, E)$ adalah $\mathrm{CF}$ dalam hipotesis asumsi evidence diketahui dengan pasti yaitu ketika $\mathrm{CF}(\mathrm{E}, \mathrm{e})=1$. Apabila terdapat dua aturan yamg mempunyai kesimpulan hipotesis yang sama, maka CF gabungan dua aturan tersebut dihitung dengan kombinasi fungsi keyakinan dengan persamaan sebagai berikut

$$
\mathrm{CF}\left(\mathrm{CF}_{1}, \mathrm{CF}_{2}\right)=\left\{\begin{array}{c}
C F 1+C F 2(1-C F 1) \\
\frac{C F 1+C F 2}{1-\min [|C F 1|, \mid C F]} \\
C F 1+C F 2(1+C F 1)
\end{array}\right.
$$

\subsection{Data Gejala dan Penyakit Kucing}

Table 2.3.1 Daftar Penyakit Kucing

\begin{tabular}{|c|c|c|c|c|c|c|c|c|c|c|c|c|c|c|c|}
\hline \multirow{2}{*}{ No } & \multirow{2}{*}{ Gejala } & \multicolumn{14}{|c|}{ Penyakit } \\
\hline & & P001 & P002 & P003 & P004 & P005 & P006 & P007 & P008 & P009 & P010 & P011 & P012 & P013 & P014 \\
\hline 1 & G001 & 98 & 98 & 95 & 98 & 95 & 90 & & & & & 98 & 80 & & 95 \\
\hline 2 & G002 & 98 & 90 & 95 & 90 & 85 & 85 & & & 70 & 95 & 98 & 30 & 98 & 95 \\
\hline 3 & G003 & 98 & & & & & & & & & & & & & \\
\hline 4 & G004 & 30 & & & & & & & & & & & & & \\
\hline 5 & G005 & 50 & & & & & & & & & & & & & \\
\hline 6 & G006 & 50 & & & & & & & & & & & & & \\
\hline 7 & G007 & & & 90 & & & & & & & & & & & \\
\hline 8 & G008 & & & 80 & & & & & & & & & & & \\
\hline 9 & G009 & & & 90 & & & & & & & & & & & \\
\hline
\end{tabular}


Jurnal Informatika Polinema

Volume: 1, Edisi: 1, November 2014

\begin{tabular}{|c|c|c|c|c|c|c|c|c|c|c|c|c|c|c|c|}
\hline \multirow{2}{*}{ No } & \multirow{2}{*}{ Gejala } & \multicolumn{14}{|c|}{ Penyakit } \\
\hline & & P001 & P002 & P003 & P004 & P005 & P006 & $\begin{array}{l}\text { P007 } \\
\end{array}$ & P008 & P009 & P010 & P011 & P012 & P013 & P014 \\
\hline 10 & G010 & & & 95 & & & & & & & & & & & \\
\hline 11 & G011 & & & 98 & & & & & & & & & & & \\
\hline 12 & G012 & & & & & & & & & & & & & & \\
\hline 13 & G013 & & & & 90 & & & & & & & & & & \\
\hline 14 & G014 & & & & & 98 & & & & & & & & & \\
\hline 15 & G015 & & & & & 99 & & & & & & & & & \\
\hline 16 & G016 & & & & & 95 & & & & & & & & & \\
\hline 17 & G017 & & & & & 99 & & & & & & & & & \\
\hline 18 & G018 & & & & & & 100 & & & & & & & & \\
\hline 19 & G019 & & & & & & 80 & & & & & & & & \\
\hline 20 & G020 & & & & & & 98 & & & & & & & & \\
\hline 21 & G021 & & & & & & 98 & & & & & & & & \\
\hline 22 & G022 & & & & & & & 98 & 98 & & & & & & \\
\hline 23 & G023 & & & & & & & 98 & 98 & & & & & & \\
\hline 24 & G024 & & & & & & & 100 & & & & & & & \\
\hline 25 & G025 & & & & & & & & 100 & & & & & & \\
\hline 26 & G026 & & & & & & & & & 98 & & & & & \\
\hline 27 & G027 & & & & & & & & & 98 & 98 & & & & \\
\hline 28 & G028 & & & & & & & & & 98 & & & & & \\
\hline 29 & G029 & & & & & & & & & 98 & & & & & \\
\hline 30 & G030 & & & & & & & & & & 95 & & & & \\
\hline 31 & G031 & & & & & & & & & & & 98 & & & \\
\hline 32 & G032 & & & & & & & & & & & \begin{tabular}{|l|}
90 \\
\end{tabular} & & & \\
\hline 33 & G033 & & & & & & & & & & & & 100 & & \\
\hline 34 & G034 & & & & & & & & & & & & 100 & & \\
\hline 35 & G035 & & & & & & & & & & & & 80 & & \\
\hline 36 & G036 & & & & & & & & & & & & 90 & & \\
\hline 37 & G037 & & & & & & & & & & & & \begin{tabular}{|l|}
90 \\
\end{tabular} & & \\
\hline 38 & G038 & & 70 & & & & & & & & & & & & \\
\hline 39 & G039 & & & & & & & & & & & & & & 80 \\
\hline 40 & G040 & & & & & & & & & & & & & & 100 \\
\hline 41 & G041 & & & & & & & & & & & & & 100 & \\
\hline 42 & G042 & & & & 75 & & & & & & & & & & \\
\hline
\end{tabular}

\section{Hasil}

Pada aplikasi sistem pakar terdapat 3 bagian utama, yaitu knowledge base (tempat penyimpanan informasi yang aktual), inference engine (proses penalaran) untuk pencarian solusi dan kesimpulan yang datanya dikirim oleh user dan faktanya tersimpan dalam knowledge base, dan user interface,(layar sajian menu untuk sistem pakar berkomunikasi dengan user).

Tempat penyimpanan atau knowledge base dapat berupa struktur data yang disimpan dalam bentuk susunan table yan saling berelasi antar satu table degan table lainnya. Data yang terkait dengan gejala dan penyebab kucing mempunyai penyakit dismpan disini. Susunan ERD yang dirancang dapat dilihat gambar 1

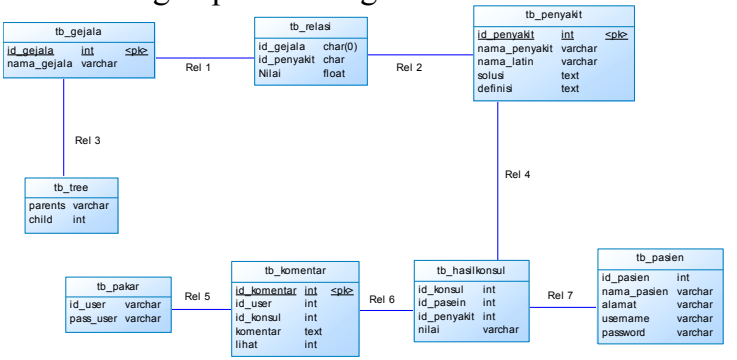

Gambar 1 Entity Relation Diagram pada knowledge base

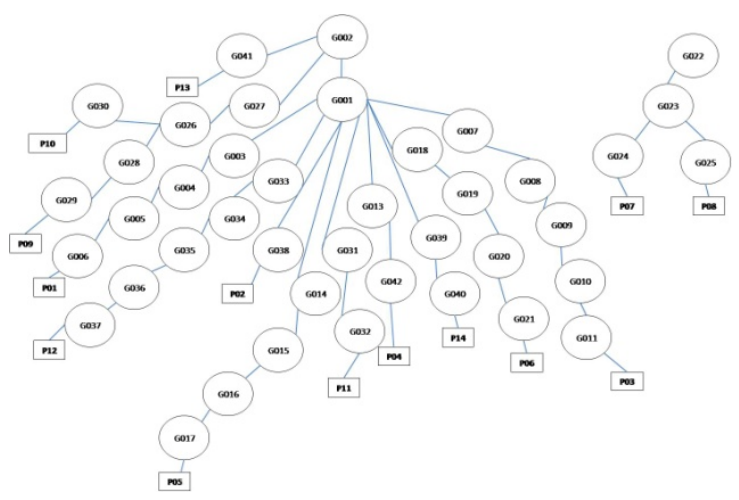

Gambar 2 Pohon Keputusan Sistem

Pohon keputusan dibangun sesuai dengan basis keputusan yang terlihat pada table. Pohon keputusan dapat dilihat pada gambar 2 yang menunjukkan bahwa penelusuran forward chaining dilakukan atas ke bawah, yaitu dimulai dari fakta gejala penyakit sampai didapatkan kesimpulan yang merupakan nama penyakit. 
Bagian lain dari sistem ini adalah tampilan user atau user interface diberikan sajian menu yang menampilkan beberapa bagian dari sistem ini sebagai berikut .

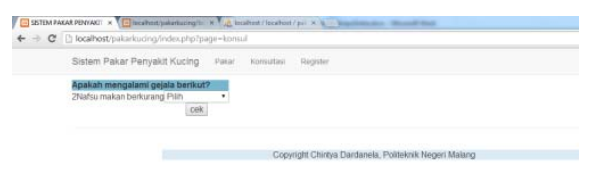

Gambar 3 Memulai Diagnosa

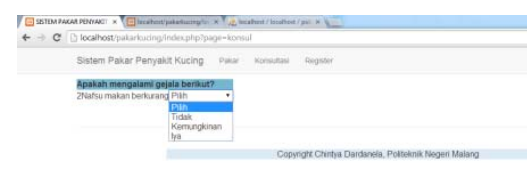

Gambar 4 input nilai $\mathrm{CF}$

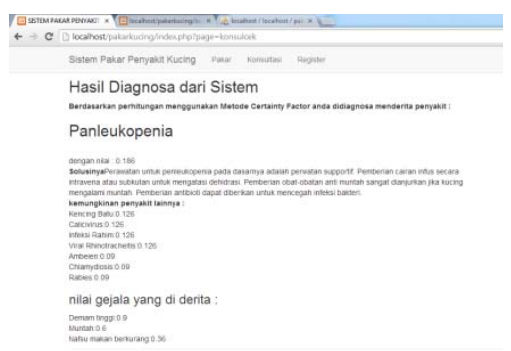

Gambar 5 Hasil akhir dari diagnosa

\section{Pembahasan}

Ketepatan hasil analisis sistem diuji dengan melakukan penilaian terhadap output sistem berdasarkan input yang diberikan user, yaitu apakah output yang dihasilkan sudah tepat apabila dinilai dari sudut pandang seorang pakar.
Sebagai contoh untuk gejala utama gatal pada penyakit Scabies yang terdapat pohon keputusan sebagaimana tampak pada penjelasan dibawah

1. Input gejala yang dialami

Gatal $=$ ya $(0.98 * 1=0.98)$

Bulu rontok $=$ iya $(0.98 * 1=0.98)$

Pada kulit kering membentuk lingkaran $=$ iya $(1 * 1=1)$

Sering terjadi ditelinga $=\operatorname{tidak}(0.1 .0=0)$

2. Cek aturan atau basis pengetahuan yang sesuai dengan gejala

3. Hitung nilai kepercayaannya

$\mathrm{CF}_{\text {pakar }}$ (gatal) $=0,98$

$\mathrm{CF}_{\text {pakar }}$ (bulu rontok) $=0,98$

$\mathrm{CF}_{\text {pakar }}$ (pada kulit membentuk lingkaran) $=$ 1

$\mathrm{CF}_{\text {pakar }}($ sering terjadi ditelinga $)=0$

Selanjutnya dihitung CFpakar dengan CFuser menggunakan persamaan $\mathrm{CF}(\mathrm{H}, \mathrm{E})=\mathrm{CF}($ user $) * \mathrm{CF}($ pakar $)$

CF $1.1=0.98 * 1=0.98$

CF $1.2=0.98^{*} 1=0.98$

CF $1.3=1 * 1=1$

Langkah terakhir adalah mengkombinasikan nilai $\mathrm{CF}$ masingmasing rule :

$\mathrm{CF}_{\mathrm{COMBINE}}=\quad \mathrm{CF} 1+\mathrm{CF} 2+\mathrm{CF} 3 *(1-\mathrm{CF} 1)$ sehingga menjadi

$\mathrm{CF}_{\mathrm{COMBINE}}=0.98+0.98+1(1-0.98)$ $=19.8$

Dengan demikian dapat dikatakan bahwa runut maju atau forward chaining dengan perhitungan certainty factor yang dilakukan pada jenis penyakit Scabies memiliki tingkat keyakinan $19.8 \%$

Tabel 4.1 Pengujian Sistem Terhadap Output Berdasarkan Pakar

\begin{tabular}{|c|c|c|c|c|}
\hline No & Gejala & Diagnosis Sistem & Diagnosis Pakar & Ketepatan \\
\hline \multirow{6}{*}{1} & Demam & \multirow{6}{*}{ Panleukopenia } & \multirow{6}{*}{ Panleukopenia } & \multirow{6}{*}{$90 \%$} \\
\hline & Nafsu makan berkurang & & & \\
\hline & Muntah & & & \\
\hline & Kejang/syok & & & \\
\hline & Suka dikamar mandi & & & \\
\hline & berliur & & & \\
\hline \multirow{3}{*}{2} & Nafsu makan berkurang & \multirow{3}{*}{ Viral Rhinotraceitis } & \multirow{3}{*}{ Viral Rhinotraceitis } & \multirow{3}{*}{$75 \%$} \\
\hline & Demam & & & \\
\hline & Tidur yang mendengkur & & & \\
\hline \multirow{7}{*}{3} & Demam & \multirow{7}{*}{ Calcivirus } & \multirow{7}{*}{ Calcivirus } & \multirow{7}{*}{$95 \%$} \\
\hline & Nafsu makan berkurang & & & \\
\hline & Mata berair & & & \\
\hline & Sempoyongan & & & \\
\hline & Nafas susah & & & \\
\hline & Bersin-bersin & & & \\
\hline & Sariawan & & & \\
\hline \multirow{2}{*}{4} & Demam & \multirow{2}{*}{ Chlamydiosis } & \multirow{2}{*}{ Chlamydiosis } & \multirow{2}{*}{$85 \%$} \\
\hline & Nafsu makan berkurang & & & \\
\hline
\end{tabular}


Jurnal Informatika Polinema

Volume: 1, Edisi: 1, November 2014

\begin{tabular}{|c|c|c|c|c|}
\hline No & Gejala & Diagnosis Sistem & Diagnosis Pakar & Ketepatan \\
\hline & Sesak nafas & & & \\
\hline & Selaput mata bengkak & & & \\
\hline \multirow{6}{*}{5} & Demam & \multirow{6}{*}{ Rabies } & \multirow{6}{*}{ Rabies } & \multirow{6}{*}{$99 \%$} \\
\hline & Bersikap gila & & & \\
\hline & susah menelan makanan & & & \\
\hline & menjadi lumpuh & & & \\
\hline & air liur menetes terus & & & \\
\hline & Nafsu makan berkurang & & & \\
\hline \multirow{5}{*}{6} & demam & \multirow{5}{*}{ Kencing Batu } & \multirow{5}{*}{ Kencing Batu } & \multirow{5}{*}{$97 \%$} \\
\hline & Nafsu makan berkurang & & & \\
\hline & Buang air kecil sedikit & & & \\
\hline & banyak minum & & & \\
\hline & $\begin{array}{l}\text { perut bagian bawah } \\
\text { keras }\end{array}$ & & & \\
\hline \multirow{3}{*}{7} & Gatal & \multirow{3}{*}{ Jamur Pada Kucing } & \multirow{3}{*}{ Jamur Pada Kucing } & \multirow{3}{*}{$100 \%$} \\
\hline & Bulu Rontok & & & \\
\hline & $\begin{array}{l}\text { Pada kulit yang kering } \\
\text { membentuk lingkaran }\end{array}$ & & & \\
\hline \multirow{3}{*}{8} & Gatal & \multirow{3}{*}{ Scabies } & \multirow{3}{*}{ Scabies } & \multirow{3}{*}{$98 \%$} \\
\hline & Bulu rontok & & & \\
\hline & sering terjadi ditelinga & & & \\
\hline \multirow{5}{*}{9} & Nafsu makan berkurang & \multirow{5}{*}{ Asetis (Hati Bocor) } & \multirow{5}{*}{ Asetis (Hati Bocor) } & \multirow{5}{*}{$92 \%$} \\
\hline & Alat indra menguning & & & \\
\hline & Kurus & & & \\
\hline & $\begin{array}{l}\text { Buang air besar yang } \\
\text { keras }\end{array}$ & & & \\
\hline & Perut membesar & & & \\
\hline \multirow{3}{*}{10} & Perut membesar & \multirow{3}{*}{ Infeksi Rahim } & \multirow{3}{*}{ Infeksi Rahim } & \multirow{3}{*}{$98 \%$} \\
\hline & Nafsu makan berkurang & & & \\
\hline & Pendarahan & & & \\
\hline & demam & & & \\
\hline & usus keluar & & & \\
\hline 11 & $\begin{array}{l}\text { buang air besar yang } \\
\text { encer }\end{array}$ & Ambien & Ambien & $98 \%$ \\
\hline & Nafsu makan berkurang & & & \\
\hline & Demam & & & \\
\hline & $\begin{array}{l}\text { bengkak pada bagian } \\
\text { tertentu menyerang } \\
\text { sistem kulit }\end{array}$ & & & \\
\hline & $\begin{array}{l}\text { pada betina terdapat } \\
\text { benjolan pada putting }\end{array}$ & & & \\
\hline 12 & $\begin{array}{l}\text { pada jantan terdapat } \\
\text { benjolan pada testis }\end{array}$ & Tumor & Tumor & $90 \%$ \\
\hline & Nafsu makan berkurang & & & \\
\hline & Jari dan telapak & & & \\
\hline & Menyerang sistem kulit & & & \\
\hline & Nafsu makan berkurang & & & \\
\hline 13 & $\begin{array}{l}\text { Bau mulut yang tidak } \\
\text { sedap }\end{array}$ & Halitosis & Halitosis & $80 \%$ \\
\hline & Nafsu makan berkurang & & & \\
\hline & Demam & & & \\
\hline 14 & Telinga kotor & Otitis & Otitis & $98 \%$ \\
\hline & $\begin{array}{l}\text { keluar cairan pada } \\
\text { telinga }\end{array}$ & & & \\
\hline
\end{tabular}




\section{Kesimpulan dan Saran}

\subsection{Kesimpulan}

Berdasarkan perancangan, implementasi dan uji coba sistem pakar penentuan penyakit kucing berbasis web, maka didapatkan kesimpulan sebagai berikut :

1. Sistem pakar penentuan penyakit kucing mampu memberikan jawaban yang sesuai dengan gejala yamg ditandai berdasarkan fakta

2. Sistem pakar yang dibangun dapat memberikan kesimpulan identifikasi berdasarkan pada urutan gejala yang sesuai dengan penyakit atau dengan perunutan forward chaining disertai dengan nilai kepercayaan menggunakan certainty factor.

3. Sistem pakar penentuan pada penyakit kucing menggunakan metode forward chaining untuk perunutan dan certainty factor untuk nilai kepercayaannya dapat mengidentifikasi penyakit dengan cukup baik. Hal ini dibuktikan dengan hasil penilaian pakar terhadap ketepatan output sistem sebesar $86.33 \%$

\subsection{Saran}

Saran yang dapat diberikan untuk pengembangan sistem ini antara lain

1. Aplikasi sistem pakar yang dibangun bisa dikembangkan menggunakan metode lain.

2. Parameter yang digunakan untuk menegakkan diagnosa pada sistem bisa menggunakan parameter selain yang digunakan pada sistem ini.

\section{Daftar Rujukan}

[DAN-10] Daniel, Gloria Virginia. 2010. Implementasi Sistem Pakar Untuk Mendiagnosis Penyakit dengan Gejala Demam Menggunakan Metode Certainty Factor. http://ti.ukdw.ac.id/ojs/index.php/informatika/article/d ownload/82/46.

Yanti, Dewi, 2008, Perancangan Sistem Pakar Diagnosis Penyakit Utama Tanaman Kelapa Sawit.

[KUS-08] Kusrini.2008. APLIKASI SISTEM PAKAR Menentukan Faktor Kepastian Pengguna dengan Metode Kuantifikasi Pertanyaan. Yogyakarta: C.V ANDI OFFSET.

[KON-08] Kong, Guilan., dkk. 2008. International Journal of Computational Intelligence Systems: Clinical Decision Support System: A Review on Knowledge Representation and Inference Under Uncertainties. http://php.portals.mbs.ac.uk/portals/49/docs/jy ang/kongxuyang_cdss_ijcis_000.pdf 